\title{
ETV6/ABL2 Fusion Gene
}

National Cancer Institute

\section{Source}

National Cancer Institute. ETV6/ABL2 Fusion Gene. NCI Thesaurus. Code C99410.

A fusion gene that results from a chromosomal translocation $\mathrm{t}(1 ; 12)(\mathrm{q} 25 ; \mathrm{p} 13)$ which fuses exon 5 of the ETV6 gene to a site within exon 1B or 2 of the ABL2 gene. This fusion may be associated with acute myeloblastic leukemia. 